\title{
Democratic Decentralisation and Social Inclusion in India: Exploring the Linkages
}

\author{
Durga Prasad Chhetri \\ Assistant Professor Department of Political Science Southfield College, Darjeeling (West Bengal)
}

\begin{abstract}
Decentralisation has been at the centre stage of institutional reforms in both the developed and developing countries. The implementation of the reforms regarding decentralisation process is essentially changing the basic social relations and the place of the citizen in the governing of the community. The decentralisation aims to enable the citizens, either directly or indirectly, to be more involved in the decision making process. Democratic decentralisation as a form of governance thus expands the participation of historically excluded and subordinated groups in the business of decision-making processes. With the decentralisation of power, the institutions became more participatory and inclusive. The inclusion of disadvantaged sections through decentralised reforms ensured equality of political opportunities.

It is in this background, this paper critically review the decentralised policy in India designed to include the historically excluded sections of society in the governing processes. The various modes of decentralization are highlighted and its linkages with social inclusion are discussed.
\end{abstract}

Key words: Decentralisation, Exclusion, Inclusion, Participation, Empowerment

\section{Introduction}

Democratic Decentralisation has been at the centre stage of institutional reforms in a large number of developing and transitional countries during the last two decades. Decentralisation reform processes have also been enthusiastically accompanied (and in some cases driven) by increased support from multilateral and bilateral donor agencies throughout the world (Work 2002) ${ }^{[1]}$. The World Bank, various United Nations Agencies, USAID and several other bilateral donors have embraced decentralisation as one of the major governance reforms on their agenda, and invested significant resources towards decentralisation programmes. The emergence of arguments for decentralisation can be linked to the disillusionment felt in different quarters, in the ability of centralised governments to oversee the development process. Development theories that provided analytical support for a centralised state began to lose ground against other theories, which supported decentralisation as a component of their world view (Lambin et al 2003) ${ }^{[2]}$. According to Bardhan and Mookherjee $(2006)^{[3]}$ the trend toward greater decentralisation has been motivated by disenchantment with previous centralised modes of governance, due in part to a perception that monolithic government breeds high levels of rent-seeking corruption and lack of accountability of government officials.

Many hope that the process of decentralisation will facilitate greater participation of communities in problem analysis, project identification, planning, implementation as well as oversight which in turn will increase ownership and the likelihood of sustainability of such initiatives. Theorists, practitioners and advocates believe that decentralisation can lead to a number of positive outcomes. These include: democratisation and participation (Crook and Manor 1998) ${ }^{[4]}$; mode of sharing powers, rural development (Uphoff and Esman $1998^{[5]}$; Ribot 2002 $2^{[6]}$ ); public service performance (World Bank 2000) ${ }^{[7]}$; 'improving' public administration (Mukhopadhyay and Meer 2004) ${ }^{[8]}$; poverty alleviation (Crook and Sverrisson 2001) ${ }^{[9]}$ relief of fiscal crisis (Olowu 2001) ${ }^{[10]}$; political and macro-economic stability (World Bank 2000) ${ }^{[11]}$; efficient policymaking (Tiebout 1956) $^{[12]}$; and national unity and state building (Mamdani $1996^{[13]}$; Bazaara 2003 ${ }^{[14]}$ ). Most of the local benefits from decentralisation are believed to come from increased popular participation, which, in turn, leads to increases in democracy, efficiency, and equity (see Agrawal and Ribot 1999 ${ }^{[15]}$; Ribot 2002 ${ }^{[16]}$ ). The decentralisation reform also ensures the participation and inclusion of marginalised and historically excluded groups in the process of governance. Effective decentralised governance that is participatory and reflective of all the interests is one of the most effective ways to facilitate inclusion. These are expected to come about by bringing government 'closer to the people' and increasing local participation as well as government accountability (World Bank $1988^{[17]}, 1997^{[18]}, 2000^{[19]}$, Manor $1999^{[20]}$ ). Hence, the decentralisation is considered as a tool for promoting development and addressing the issue of social exclusion. The major promise of democratic decentralisation, according to Blair $(2000)^{[21]}$, is that by building popular participation and accountability into local governance, government at the local level will become more responsive to citizen desires and more effective in service delivery. Decentralisation of authority and power increases efficiency, 
accountability, equity, democracy and participation which are all considered to be an important devises to tackle the social exclusion. The decentralisation processes have opened space for civil society and empowerment, giving citizens opportunities to better participate in decision-making processes and administration. Decentralization leads to greater participation and inclusion.

Decentralisation reforms, according to Ribot (2002) ${ }^{[22]}$ typically are promoted to achieve six broad objectives:

1. dismantling or downsizing central government,

2. consolidating national unity,

3. consolidating central power (by shedding risks and burdens),

4. increasing local participation and local democracy,

5. improving the efficiency and equity of local service delivery, and

6. strengthening local government.

\section{Defining Decentralisation}

Decentralisation is usually referred to as the transfer of powers from central government to lower levels in a political-administrative and territorial hierarchy (Crook and Manor 1998 ${ }^{[23]}$; Agrawal and Ribot $1999^{[24]}$ ). Mawhood $(1983)^{[25]}$ and Smith $(1985)^{[26]}$ defines decentralisation as any act by which central government formally cedes powers to actors and institutions at lower levels in a political administrative and territorial hierarchy. The definition by Rondinelli and Cheema $(1984)^{[27]}$ is one of the best general definitions of decentralisation. According to them, decentralisation is the transfer of responsibility for planning, management and resource utilisation and allocation from the central government to (a) field units of central government ministries or agencies; (b) subordinate units or levels of government; (c) semi-autonomous public authorities or corporations; (d) are-wide regional or functional authorities. Decentralisation is understood as the restructuring of authority so that there is a system of co-responsibility between institutions of governance at the central, regional, and local levels according to the principles of subsidiarity thus increasing the overall quality and effectiveness of the system of governance, while increasing the authority and capabilities of sub-national levels. Decentralisation, to Hans Bjorn Olsen $(2007)^{[28]}$, is the transfer of authority and responsibility for public functions from the central government to intermediate and local governments or quasi-independent government organizations and/or the private sector. Decentralisation has also been defined as the assignment, transfer or delegation of political, administrative and fiscal responsibilities to lower levels of government ${ }^{\mathrm{i}}$.

From a good governance perspective, decentralisation refers to the restructuring or reorganisation of authority so that there is a system of co-responsibility between and among institutions of governance at central, regional and local levels according to the principle of subsidiarity ${ }^{\mathrm{ii}}$, while increasing the authority and capacities of sub-national levels ${ }^{\text {iii. }}$.

Treisman $(2002)^{[29]}$ defines decentralisation as a characteristic of compound government systems. Compound government structures are those that include overlapping territorial jurisdictions. To put it in layman's terms, decentralised systems have multiple levels of governments that are territorially defined. The first level is the national government, followed by state or provincial governments, and then local governments based on units like counties, districts, and cantons.

\section{Forms of Decentralisation}

Theorists of decentralisation have put forward four forms of decentralisation: deconcentration, delegation, devolution and privatisation ${ }^{\text {iv }}$.

(i) Deconcentration refers to the process of administrative decentralisation whereby the central government designs a structure that enables its agents to work close to the local people in field units/agencies of central government. The deconcentration of the administrative system thus involves setting up region or district offices of the central ministries and other state agencies followed by delegation of work and authority from the centre to these local representations of central authorities. Deconcentration can take different forms (Siedentopf 1985) ${ }^{[30]}$ :

a) Mere shifting of workload from a central government ministry to its offices outside the national capital. The local staffs do not possess the authority to make decisions on their own or to carry them out.

b) Transfer of some decision-making authority to a system of field administration, allowing it some latitude to plan, to make routine decisions and adjust the implementation of central directives to local conditions, within guidelines set by the central ministry.

c) Establishment of subordinate levels of government to perform local functions but under the technical supervision and control of the central ministry. Delegation is a more extensive form of decentralisation and it is through delegation central governments transfer responsibility for decision-making and administration of public functions to semi-autonomous organisations not wholly controlled by the central government, but ultimately accountable to it. 
(ii) Delegation, compared to deconcentration, provides greater opportunities to agencies and units to exercise delegated functions and responsibilities. In terms of dimension both deconcentration and delegation can be termed as administrative decentralisation with the central government retaining ultimate authority.

(iii) Devolution is a real form of decentralisation which involves the process of transferring decision-making and implementation powers, functions, responsibilities and resources to legally constituted local governments. This system gives local authorities autonomy within clearly demarcated areas of decisionmaking through constitutional rights.

According to Rondinelli $(1981)^{[31]}$ devolution has certain characteristics. First, it requires that local government be given autonomy and independence, and be clearly perceived as a separate level over which central authorities exercise little or no control. Second, local units must have clear and legally recognized geographical boundaries over which they exercise authority. Third, local government units must be given corporate status and power to raise sufficient resources to perform specified functions. Fourth, devolution implies that local governments are institutions which provide services that satisfy the needs of local citizens and allow their participation in local affairs. Finally, devolution establishes reciprocal, mutually beneficial and coordinative relationships between central and local governments.

(iv) Privatisation a relatively new phenomenon refers to transfer of responsibility for public functions to voluntary organizations or private enterprises. The objective is to mobilise the capacity and initiatives of civil society organizations working for social and economic development.

Of the four forms of decentralisation described above, only devolution is considered as genuine form of decentralisation. Devolution provides the largest scope for developing genuine local-level governance based on popular participation. The deconcentration amounts to the least amount of transfer of power to local people while the delegation also does not by itself transfer power to the locals, although the delegated agencies have the scope for involving local people in their decision-making process.

\section{Decentralisation and Social Inclusion: Linkages}

In the discourse of governments and international aid agencies, decentralisation appears as a solution to several core problems: efficiency deficits, fiscal crises, governance failures, government legitimacy, or even inequity (World Bank 1997 ${ }^{[32]}$; World Bank 200 ${ }^{[33]}$ ). Further the institutional reforms through decentralisation have contributed to greater inclusion of historically excluded groups, minority and poor within the nation-state by increasing their number in the institutions of local self-government. Social exclusion is the concern of every government since it involves the denial of access to social spaces, ownership, and control over resources, denial of opportunities and basic needs, denial of right to representation and participation in social, economic, and political participation. The way forward to social exclusion should be the inclusion of disadvantages and marginalised groups in all the development aspects. The process of decentralisation, in this connection, is viewed as one of the most important projects for reorganisation of the life of the society. The decentralisation aims to enable the citizens, either directly or indirectly, to be more involved in the decision making process. The implementation of the reforms regarding decentralisation process is essentially changing the basic social relations and the place of the citizen in the governing of the community. Therefore, decentralisation in most of the countries including India, especially in the arena of social policies, was therefore driven by the idea of reducing social inequalities and correcting allocative distortions. Hence, the high centralisation, bureaucratism, low accountability and lack of the inclusion and participation of society in the public policy-making were the elements attacked by the decentralisation strategy in a democratic context. Advocates of decentralisation extol its many virtues, including the inclusive growth. Supporters project that decentralisation will lead to more efficient policymaking (Tiebout1956) ${ }^{[34]}$ and other including Crook and Manor $(1998)^{[35]}$ argue that decentralisation plays an important role in the democratisation and people participation, public service performance, poverty alleviation and political and macroeconomic stability. Decentralisation theorists and policy makers evoke developmentalist arguments contending that the increased efficiency, equity and inclusion that should arise from decentralisation results in better and more sustainable management (Larson and Ribot $2004)^{[36]}$. Decentralisation reform therefore tries to address the different causes of social exclusion like social inequalities, poverty, corruption, ineffectiveness and poor governance. As most of the local benefits from decentralisation are believed to come from increased popular participation, which in turn, leads to increase in democracy, efficiency and equity (Agarwal and Ribot $1999^{[37]}$ and Ribot $2002^{[38]}$ ). The positive outcomes of decentralisation include greater participation and inclusion. Hence, the decentralisation reforms initiated by governments of various countries have opened space for civil society and empowerment, giving citizens opportunities to better participate in the planning and decision-making processes. The ethnic minorities and other social groups who were otherwise previously marginalised and excluded are started getting involved in community affairs and got a better opportunity to influence local development under this reform policy. Brady, Schlozman and Verba (1999) ${ }^{[39]}$ also opines that since the government is nearby and more accessible, citizens will feel like they can make a difference and have an impact on decisions process, leading to greater political 
efficacy and trust. More decentralisation would lead to creation of inclusive, responsible and accountable governance which in turns lead to empowerment and inclusion of disadvantaged sections of society (see Fig.1). One can conclude from the above analysis that there is a causal relationship between decentralisation and social inclusion. Decentralisation reforms if implemented properly encourage the citizens who are on the margins of society to participate effectively in the local decision making and power structures.

This leads to the important policy conclusion that decentralisation reforms should go together with the implementation of other policies and be part of a larger plan to empower the excluded and reduce disparities in society.

\section{Contextualising Decentralisation in India}

Decentralisation is being widely recognized in all developing countries as a vital strategy for ensuring grass-root level democracy and participatory development. India has repeatedly experimented with decentralisation in the colonial, post-colonial and post independence period. The first initiative of decentralisation in the country dates back to the year 1882 when Ripon Resolution was enacted. Since then a considerable number of decentralization initiatives have been taken by different governments in various forms. The launch of Community Development Programme and National Extension Service in 1952/53 is the first initiatives of the government in post independence era. This was followed by the appointment of various committees and commissions (Balwantrai Mehta Committee (1957), K. Santhanam Committee 1963, Ashok Mehta Committee 1978, GVK Rao Committee 1985, L.M. Singhvi Committee 1987) to reforms the decentralised structure of government at the local level. The avowed objectives of these reform initiatives had been building as well as strengthening the capacity of local level organisations particularly of Local Government Institutions and in the process to create scopes and opportunities for the participation of community people in the management of local affairs. With the enactment of $73^{\text {rd }}$ and $74^{\text {th }}$ Constitutional Amendment Acts in the early-1990s, the process of decentralisation has further increased in all areas of social and public policy. This was primarily a result of the political democratisation and liberalisation reforms, but also can be construed as part of a longer trend towards decentralisation. This reform towards democratic decentralisation has been driven by the need to deepen the process of democracy by giving citizens a greater say in matters which impact more on their daily lives. This has been referred to as bringing government to the 'doorsteps' of the people or promoting 'grass roots' democracy. In contrast to previous decentralisation efforts these attempts were conceived in the context of people's participation and empowerment of local bodies. Thus one may find here a difference in objectives of decentralisation move of colonial period and post independence period. The ultimate objective of the colonial regimes was to consolidate the colonial power rather than decentralisation of power and hence the decentralisation efforts taken and implemented during the British colonial rule had been piecemeal, narrow and restrictive in nature. The motive behind the decentralisation reforms after independence is to strengthen and enhanced community participation in decision-making, enabled local communities to determine their local leadership through democratic elections, provide institutionalised structural arrangements for participatory development planning. Further the models adopted in the 1990s differ considerably with respect to the composition of local government institutions and to the powers and resources that they should control. The local government of present day are more inclusive, democratic and participatory in nature and enjoy more powers and functions. There are at present about 241547 local governments (3723 urban local bodies and 237824 rural local bodies) in India. The local governments are known as panchayats in rural areas and municipalities in urban areas. The Constitutional Amendment $\left(73^{\text {rd }} \& 74^{\text {th }}\right)$ Acts have accorded the constitutional status to the rural and urban local bodies and clearly define the powers and responsibilities of the local bodies. Except few, in most of the states the panchayats have three-tier system: Gram panchayats at village level, Panchayat Samities at block level and Zilla Parishad at district level. And all the states have three-tier municipal bodies viz. Municipal Corporation in big cities and towns; Municipal Councils in small cities and towns and Nagar Panchayats in rural-urban transition areas. Besides the creation of uniform three tier local bodies in rural and urban areas, the constitutional Acts also reserved the 33 per cent of seats for women, scheduled castes and tribes in panchayats and municipalities. The constitution of an independent State Election Commission to conduct the regular election and State Finance Commission for reviewing and augmenting the resources of local governments are the other important features of Amendment Acts.

\section{Dimensions of Decentralisation and Social Inclusion in India}

Many believe that decentralisation increases popular participation in decision-making because it brings government closer to people which are not possible in the centralised governance. Through people's participation in decision-making, planning, implementation and monitoring and backed by appropriate institutions and resources, it can go a long way in improving the quality of life, particularly of the poorer and marginalised segments of population. Decentralisation reforms in India, particularly after enactment of $73^{\text {rd }}$ and 
$74^{\text {th }}$ Amendment Acts, served as an important mechanism for social inclusion through enhancing the participation of the disadvantaged groups in local governance. It seeks to promote greater participation of marginalised groups within political processes, through addressing inequalities associated with gender, class, race, ethnicity, caste, disability and sexuality, among other variables, and greater accountability of governments towards those who have traditionally been excluded from political action. This new democratic variant of decentralisation introduced in early 1990s in the country increases participation, accountability and transparency and efficiency in local governance, along with empowerment for previously marginal groups. According to the logic of current decentralisation, efficiency is linked to local enfranchisement or the broad-based inclusion of local people in public decision making. Recent theorists of decentralization assert that "underlying most of the purported benefits of decentralisation is the existence of democratic mechanisms that allow local governments to discern the needs and preferences of their constituents, as well as provide a way for these constituents to hold local governments accountable to them" (Smoke 1999) ${ }^{[40]}$. The more accountable local authorities are to the population, the more inclusive their decisions are likely to be. Adablah $(2003)^{[41]}$ and Mani $(2003)^{[42]}$ argued that local authorities tend to act more in line with local preferences and conditions, and their response to local needs is more expeditious. Decentralisation provides opportunities to marginalised segments, such as women, minorities, etc., to participate at the local level, enabling a more sensitive approach to policy formulation and implementation. It is quite obvious that decentralisation provides opportunities for more people, including the underrepresented groups (like women, poor, minorities) to participate in decisions that affect their lives. An effective decentralisation creates inclusive, accountable, responsive and participatory local institutions which can help to come out of social exclusion. The greater the degree of decentralisation, more inclusive and responsive is the governance and hence greater the degree of empowerment of marginalised sections of population (see Fig. 1). Figure 1 shows that there is a significant relationship between decentralisation (political, administrative and fiscal) and social inclusion.

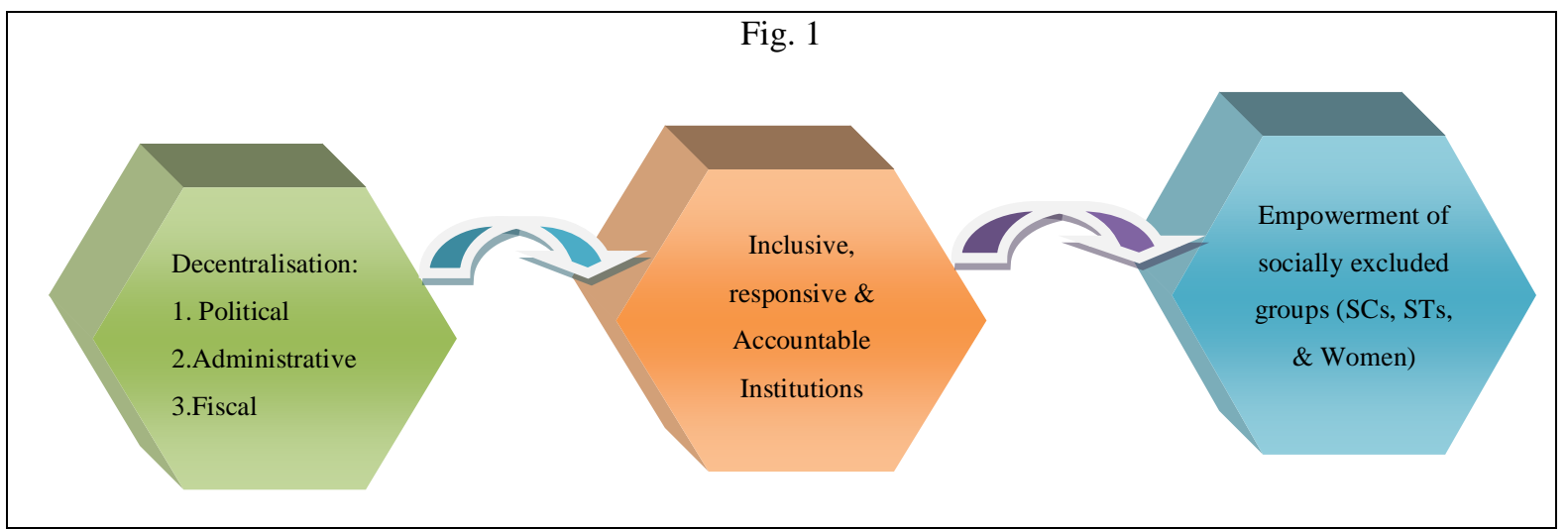

Political Decentralisation: Among the different dimension of decentralisation, the political decentralisation is the most important one which aims to give citizens and their elected representatives more power in decisionmaking. It is concerned with transfer of political power and authority from national to sub-national levels of government. Devolution, which involves full transfer of responsibility, decision-making, resources, and revenue generation to an independent and autonomous local-level public agency, is considered a form of political decentralisation.

The main aim of political decentralisation is to give citizens or their elected representatives more power in decision-making and to support the process of democratisation by giving citizens and their representatives, more influence in the formulation and implementation of public policies. This is particularly important in a country like ours, where broad segments of the poor have been marginalised and excluded with respect to political decision-making. From this perspective, decentralisation is a tool to improve the legitimacy of the democratic system (Larson and Ribot 2004) ${ }^{[43]}$. Although democracy is not a necessary part of decentralisation, its presence can have a significant influence on the perceived legitimacy of decentralised systems. The democratic decentralisation process enlarged the democratic potential of local governments, empowered them and helped to emerge as true self-governing institutions. It facilitates the process of political participation and arouses the confidence of people of all social sections including the minorities and socially excluded communities in local democracy and development. Decentralisation strengthens citizen participation by bringing governments closer to the people they are intended to serve (Shah 1998) ${ }^{[44]}$. Advocates of political decentralisation contend that decisions made with greater participation will be better informed and more relevant to diverse interests in the society than those made solely by national political authorities. Political 
dimensions of decentralisation are therefore generally concerned with increasing public participation through citizens being actively engaged in public institutions.

Democratic decentralisation provided space for the deprived and marginalised social sections for their collective bargain and to get their due share in local governance and development process. Decentralisation and democratisation process helps to protect the interests of the most excluded social groups like scheduled castes, scheduled tribes and women. The provisions like Gram Sabha (Art.243A), direct election \{(Art. 243B (2)\}, reservation of seats (Art. 243D) for SCs, STs and women etc. encourage the poor and marginalised citizens to participate in the development process and hence central in social inclusion of deprived classes. The 73rd Amendment mandated that seats be reserved for SCs, STs, and women as a means of partially correcting longstanding, social inequalities. A minimum of $1 / 3$ of all seats in local bodies are to be reserved for women. Seats are to be reserved for SC/STs in proportion to their population in each constituency-one third of these must be reserved for women. The election of representatives from local electoral jurisdictions allows citizens to know better their political representatives and allow elected officials to know better the needs and desires of their constituents. Elected local governments may also be more accountable to the community and inclusive of the poor in decision and policy-making. In India, for example, an astonishing two million rural women have held office on the local and regional level since 1993. This has been made possible by a constitutional mandate that reserves one third of all local seats in the panchayat raj system of governance. The reservation of seats in the local bodies also increases the number of SCs and STs representatives. The reservation have improved the physical/numerical presence of women and SC/STs in elected bodies and has been successful in ensuring that they have an equal voice in PRI deliberations, in particular at the village level. Hence, the overall increase in opportunities brought about by the decentralisation reforms for participation in the democratic processes of society and the policy of reservations in particular has created an enabling environment for the underprivileged and historically excluded groups of society. Reservations in the legislature, panchayats and municipalities have provided a space for SCs and STs in the executive and the decision-making process. The formal reservation policy in the government sector has also contributed to an improvement in the human development of SCs and STs. The political decentralisation thus play a important role in addressing the issues of social exclusion through increased participation of historically excluded groups in local government to influence policy and decisions regarding pro-poor programmes, and improved services for the poor and marginalised. It is believed that participatory local governments are in a better position to assess needs at the local level, monitor and control development of local communities, and provide more responsive services.

Administrative Decentralisation: Administrative decentralisation or deconcentration involves the transfer of managerial duties and decisions to local administrative bodies, in order to improve the quality of public policies and services (Larson and Ribot 2004) $)^{[45]}$. Rondinelli and Nellis (1986) ${ }^{[46]}$ define administrative decentralisation as "... the transfer of responsibility for planning, management, and the raising and allocation of resources from the central government and its agencies to field, units of government agencies, subordinate units or levels of government, semi-autonomous public authorities or corporations, area-wide regional or functional authorities, or non-governmental private or voluntary organizations."

Administrative decentralisation, also known as deconcentration, refers to a transfer to lower-level central government authorities, or to other local authorities who are upwardly accountable to the central government (Ribot 2002) ${ }^{[47]}$. This type of decentralisation encompasses deconcentration with delegation of authority and devolution of functions. The main goal of decentralisation here is to do better justice to the preferences and interests of the local population by bringing the decision-making process closer to them. To empower the local institutions, the central Act has broadly defined powers and functions to be devolved to PRIs, from the indicative list of 29 functions in the Eleventh Schedule of the Constitution. The 29 functions listed under Eleventh Schedule (Art. 243G) are directly or indirectly related to the empowerment and upliftment of women, SCs and STs. This apart, a large number of institutional structures have been innovated as a part of participatory planning to engage the citizens in the political process at the local level and to identify and prioritize their felt needs and protecting their democratic rights. Planning, especially the decentralised planning has been used a tool for political mobilisation and strengthening the capacity of people to engage in the decision making process of local governments. All these measures appear currently to be particularly effective in terms of improving opportunities for poor and vulnerable people, especially women and tribals, to meet their own social and economic development objectives.

Fiscal Decentralisation: Financial responsibility is a core component of decentralisation. Decentralisation initiatives that focus exclusively on electoral and administrative processes without considering the fiscal dimensions will not be sustainable. For local governments and private organisations to carry out decentralisation effectively, they need adequate revenues as well as the authority to make decisions on expenditures. Lack of 
adequate funding for lower level units was the single most important factor that undermined many of the decentralization attempts in 1970's and 80's. The four pillars of fiscal decentralisation are:

(i) The assignment of expenditure responsibilities to different government levels

(ii) The assignment of tax and revenue sources to different government levels

(iii) Intergovernmental fiscal transfers

(iv) Sub-national borrowing

To be genuinely supportive of a decentralisation process, the basic characteristics of a system for decentralised financial management should include: (a) transparency of allocation (b) predictability of the amounts available to local institutions and (c) local autonomy of decision making on resource utilisation (UN 1996) ${ }^{[48]}$. Under new dispensation, the Amendment Act devolves some powers and responsibilities to panchayats in regards to the preparation of plan for economic development and social justice. Likewise, Act also devolves the power to panchayats to impose, collect taxes, fees etc. to enable or empower them to carry out their functions and responsibilities. The State Finance Commission has created for recommending resource allocation and creation. Further a sizeable amount of Special Component Plan (SCP), Tribal Sub Plan (TSP) and Women Component Plan (WCP) have been devolved to the local governments and ensured their active participation in the formulation and implementation of development programmes for these social sections. The fund earmarked as Special Component Plan shall be utilised only for those projects beneficial to SCs, STs and Women. The provision has been made to devolved adequate fund to the local governments for the social inclusion of SCs and STs by taking up livelihood promotion programmes. Thus the efforts taken by the democratic decentralisation process substantially helped the socially excluded communities for mainstreaming them in to development process at the local level.

Table 1. Status/Level of Decentralisation in India and South Asian Nations

\begin{tabular}{|l|c|c|c|c|c|}
\hline Country & \multicolumn{5}{|c|}{ Status of Decentralisation } \\
\hline & Legislated & Political & Administrative & Fiscal & Overall \\
\hline India & Yes & High & Medium & Low & Medium \\
\hline Bangladesh & Yes & Medium & Medium & Low & Medium \\
\hline Bhutan & No & Low & Low & Low & Low \\
\hline Pakistan & No & Medium & Medium & Low & Medium \\
\hline Sri Lanka & Yes & High & Medium & Medium & Medium \\
\hline
\end{tabular}

\section{(Source: Allen L. Clark)}

Of the three dimensions of decentralisation, the political decentralisation is found to have a huge positive impact on social inclusion by virtue of the involvement of marginalised and poor people in decision making, planning, implementation and basic service delivery. More specifically, the political decentralisation seeks to promote greater participation of marginalised groups within political processes through addressing inequalities associated with caste, ethnicity and gender. The poor and the disadvantages group in the country are experiencing benefits. The administrative and fiscal decentralisation too has provides a structural arrangement for popular or community participation in governance and development. Decentralisation of specific services such as health and education has been attempted in the country through administrative decentralisation. Since the status of fiscal decentralisation in India is low (see Table 1), this dimension of decentralisation demonstrate less impact on the social inclusion of disadvantages and poor in the governing processes.

\section{Conclusion}

The discussion in this paper has enabled us to show that a decentralisation reform in India is an ambitious process that seeks to empower local communities to engage in their own development. This is a departure from most past decentralisation efforts which were geared only in the direction of administration. The objectives of decentralisation in India give decentralised governance a development mission and call up on local communities (including SC/STs and women) to shape their destiny. Decentralisation has enhanced participation in decisionmaking, enabled local communities to determine their local leadership through democratic elections, provided institutionalised structural arrangements for participatory development planning, and for involving marginalised groups such as women, SCs and STs in decision-making. Through decentralisation, the vast majority of civic bodies hitherto excluded from the development planning and implementation process would become actively engaged with formal governmental institutions. Hence, democratic decentralisation, when well structured, provides institutional infrastructure - representation and meaningful powers - for sustained inclusion. The inclusion of disadvantaged sections has in principle ensured equality of political opportunities. In India, a movement towards democratic decentralisation has been driven by the need to deepen the process of democracy by giving citizens a greater say in matters which impact more on their daily lives. The creation of institutions like Gram Sabha, accountability mechanisms, people's planning etc. lead to establishment of inclusive self- 
governance. And the main goal of inclusive governance is to include those who have traditionally been excluded from political action and reduce disparities in society. The success of democratic decentralisation depends largely on the achievement to include former marginalised groups in local decision-making and power structures effectively. Previously, many people on the basis of their social positioning - whether according to caste, ethnicity or gender - are excluded from certain social, economic and political opportunities. However, the decentralisation efforts in the country since early 1990's created an opportunities to all and enabled all disenfranchised and disadvantages groups to emerge as empowered participants in local democratic processes. Decentralisation through the process of democratisation created an enabling environment and act as a tool for social inclusion through enhancing the participation of the disadvantaged groups in local governance.

\section{Endnotes}

i. This definition is common in World Bank publications. For example, see Litvack, J., Ahmad, J. and Bird, R., 1998, Rethinking Decentralisation in Developing Countries, Sector Studies Series, The World Bank, Washington DC, p. 6. Where emphasis is placed on the transfer of administrative, fiscal and political power (instead of responsibilities), the term democratic decentralization is frequently used. Delegation, by contrast, implies the transfer of managerial and resource allocation authority from the centre to "field" offices and deconcentrated units. See M J Balogun, "The Scope for Popular Participation in Decentralization, Community Governance and Development: Towards a New Paradigm of Centre-Periphery Relations”, Regional Development Dialogue, Vol. 21, No. 1, Spring 2000, pp. 154-158.

ii. Based on the principle of subsidiarity, functions are transferred to the lowest level that is capable or potentially capable of delivering the function.

iii. This definition was put forward by the UNDP Management Development and Governance Division, Bureau for Development Policy, 1997, Decentralised Governance Programme: Strengthening Capacity for PeopleCentred Development, p.4. See also Balogun, The Scope for Popular Participation in Decentralization, Community Governance and Development, op. cit., pp. 159-163.

iv. The main source of these descriptions of forms is Rondinelli, op. cit., p. $137-139$ and UNDP, op. cit. p. 5 6. According to other commentators, "privatization" raises issues that are fundamentally different from those of decentralization. They therefore dismiss the former as a sub-set of the latter. See Balogun, The Scope for Popular Participation in Decentralization, Community Governance and Development, op. cit., pp. 155 and 157.

11] Robertson Work, Overview of Decentralization Worldwide: A Stepping Stone to Improved Governance and Human Development, Second International Conference on Decentralization Federalism: The Future of Decentralizing States? Manila, Philippines, UNDP/Bureau of Development Policy (2002), available at www.undp.org/governance/docsdecentral/overview-decentralisationworldwide-paper.pdf

[2] Eric Lambin, Helmut Geist and Erika Lepers, 'Dynamic of Land-use and Land-cover Change in Tropical Regions', Annual Review of Environment and Resources, vol. 2(3), 2003, 205-241

[3] P. Bardhan, and D. Mookherjee Decentralization, Corruption, and Government Accountability: An Overview in S. Rose-Ackerman and E. Edgar (eds.) A Handbook of Economic Corruption (Cheltenham, UK and Northampton MA, USA 2006).

[4] R.C. Crook and J. Manor, Democracy and Decentralisation in South Asia and West Africa: Participation, Accountability and Performance (Cambridge, Cambridge University Press 1998).

[5] Norman Uphoff, Milton J. Esman and A. Krishna, Reasons for Success: Learning from Instructive Experiences in Rural Development (New Delhi, Vistaar1998).

[6] J.C. Ribot, African Decentralization: Local Actors, Power and Accountability, Democracy, Governance and Human Rights Working Paper No.8, Geneva, UNRISD and IDRC 2002.

[7] World Bank, Entering the 21st Century, World Development Report 1999/2000 (Oxford, Oxford University Press 2000).

[8] Maitrayee Mukhopadhya and Shamin Meer, Creating Voice and Carving Space, Redefining Governance from Gender Perspective, Royal Tropical Institute, KIT Development Policy and Practice, The Netherland 2004.

[9] R.C. Crook and A.S. Sverrisson, Decentralization and Poverty-Alleviation in Developing Countries: A Comparative Analysis or, is West Bengal Unique? IDS Working Paper 130. Institute for Development Studies, Brighton 2001.

[10] B. Olowu, African Decentralisation Policies and Practices from 1980s and Beyond, Working Paper Series 334, The Hague: Institu te of Social Studies 2001

[11] World Bank, Entering the 21st Century, World Development Report 1999/2000 (Oxford, Oxford University Press 2000).

[12] Charles Teibout, A Pure Theory of Local Expenditures, Journal of Political Economy, vol. 64, 1956, $416-424$.

[13] M. Mamdani, Citizen and Subject: Contemporary Africa and the Legacy of late Colonialism (Kampala, Cape Town \& London: Fountain Publishers, David Philip \& James Currey 1996).

[14] N. Bazaara, Decentralization, Politics and Environment in Uganda, Environmental Governance in Africa Working Paper Series No.7, World Resources Institute, Washington, DC, 2003.

[15] A. Agarwal, and J.C. Ribot Accountability in Decentralization: A Framework with South Asian and West African Environmental Cases, The Journal of Developing Areas, vol. 33, 1999, 473-502.

[16] J.C. Ribot, African Decentralization: Local Actors, Power and Accountability, Democracy, Governance and Human Rights Working Paper No.8, Geneva, UNRISD and IDRC 2002

[17] World Bank, World Development Report (New York, Oxford University Press1988).

[18] World Bank, World Development Report, (New York, Oxford University Press 1997). 
[19] World Bank, Entering the 21st Century, World Development Report 1999/2000 (Oxford, Oxford University Press 2000).

[20] James Manor, Direction in Development: The Political Economy of Democratic Decentralisation, Washington D.C., World Bank 1999.

[21] H Blair, Participation and Accountability at the Periphery: Democratic Local Governance in Six Countries, World Development, vol.28 (1), 2000, 21-39

[22] J.C. Ribot, Democratic Decentralisation of Natural Resources: Institutionalising popular participation 2002.

[23] R.C. Crook and J. Manor, Democracy and Decentralisation in South Asia and West Africa: Participation, Accountability and Performance (Cambridge, Cambridge University Press 1998).

[24] Aggarwal and Ribot, Accountability in Decentralization: A Framework with South Asian and West African Environmental Cases, The Journal of Developing Areas, vol. 33, 1999, 473-502.

[25] P. Mawhood, Local Government in the Third World, (Chichster, John Wiley 1983).

[26] B.C. Smith, Decentralization: The Territorial Dimension of the State (London, George Allen 1985).

[27] D.A. Rondinelli and Shabbir G Cheema, Decentralisation in Developing Countries: A Review of Recent Experience, Washington DC, World Bank, 1984.

[28] Hans Bjørn Olsen, Decentralisation and Local Governance, SDC, 2007.

[29] Daniel Treisman, 'Defining and Measuring Decentralization: A Global Perspective', 2002, available at URL: www.sscnet.ucla.edu/polisci/faculty/treisman/pages/de ${ }^{-}$n.PDF

[30] H. Siedentopf, 'Proposal for the Project on the Studies of Decentralization for Rural Development', Mimeo 1985.

[31] D.A. Rondinelli, 'Government Decentralisation in Comparative Perspective: Theory and Practice in Developing Countries', International Review of Administrative Sciences, vol. 47(2), 1981,133-145.

[32] World Bank, World Development Report, (New York, Oxford University Press 1997).

[33] World Bank, Entering the 21st Century, World Development Report 1999/2000 (Oxford, Oxford University Press 2000).

[34] Charles Teibout, A Pure Theory of Local Expenditures, Journal of Political Economy, vol. 64, 1956, $416-424$.

[35] R.C. Crook and J. Manor, Democracy and Decentralisation in South Asia and West Africa: Participation, Accountability and Performance (Cambridge, Cambridge University Press 1998).

[36] AM Larson and J.C. Ribot, Democratic decentralisation through a natural resource lens: An Introduction, European Journal of Development Research, vol. 16(1), 2004, 1-25.

[37] Aggarwal and Ribot, Accountability in Decentralization: A Framework with South Asian and West African Environmental Cases, The Journal of Developing Areas, vol. 33, 1999, 473-502.

[38] J.C. Ribot, African Decentralization: Local Actors, Power and Accountability, Democracy, Governance and Human Rights Working Paper No.8, Geneva, UNRISD and IDRC 2002.

[39] Henry Brady, Kay Schlozman and Sidney Verba Prospecting for Participants: Rational Expectations and the Recruitment of Political Activists, American Political Science Review, vol. 93 (1), 1999, 153-168.

[40] Smoke, Decentralization and Health in the Philippines and Indonesia: An Interim Report, 1999, available from http://www.sti.ch/pdfs/swap243.pdf, accessed March 2011

[41] Cornelius Adablah 'The Role of Civil Society in Decentralized Governance for Poverty Alleviation: The Experience of West Africa', presented in the workshop on Decentralization and Poverty Reduction, Dakar, Senegal 2003.

[42] Devyani Mani, 'Human Security and Decentralized Planning: The Training Experience of UNCRD' presented in the workshop on Decentralization and Poverty Reduction” Dakar, Senegal 2003.

[43] AM Larson and J.C. Ribot, Democratic decentralisation through a natural resource lens: An Introduction, European Journal of Development Research, vol. 16(1), 2004, 1-25.

[44] A. Shah, 'Balance, Accountability, and Responsiveness: Lessons about Decentralization', Washington, D.C., World Bank 1998.

[45] AM Larson and J.C. Ribot, Democratic decentralisation through a natural resource lens: An Introduction, European Journal of Development Research, vol. 16(1), 2004, 1-25.

[46] D. Rondinelli and J. Nellis 'Assessing Decentralization Policies: A Case for Cautious Optimism', Development Policy Review, vol. 14(1), 1986, 5 .

[47] J.C. Ribot, African Decentralization: Local Actors, Power and Accountability, Democracy, Governance and Human Rights Working Paper No.8, Geneva, UNRISD and IDRC 2002

[48] United Nations, Report of the United Nations Global Forum on Innovative Policies and Practices in Local Governance, Gothenburg, Sweden, 23-27 September 1996, ref St/Tcd/Ser.E/46, p. 48 